\title{
Assessing Storage Insect Pests and Faecal dropping of Rodent in Stored Grains in two districts of Southwestern Ethiopia
}

Marid Tadesse ( $\square$ mtaddese19@gmail.com )

Ethiopian Technical University

Md Jamshed Ali

Ethiopian Technical University

\section{Research Article}

Keywords: Sorghum, Storage Pests, Grain Damage, Grain Loss, Maize

Posted Date: July 30th, 2021

DOI: https://doi.org/10.21203/rs.3.rs-670493/v2

License: (c) (i) This work is licensed under a Creative Commons Attribution 4.0 International License. Read Full License 


\section{Abstract}

This study was designed to assess major insects and occurrence of rodent infestation in stored grain in two districts of south western Ethiopia. Omo Neda and Bako Tibe districts were purposively selected supported their potential growing of maize and sorghum grain, and high postharvest losses in these selected areas. A total of 160 farmers' stores from both districts were randomly selected. The grain samples used in the present study were stored for 5 different time periods, ranging from 1 to 5 months and from the same farmers' stores, to identify storage insect pest and to determine grain weight loss and insect damage. The results showed that the dominant insect species in maize and sorghum grains were weevils (Sitophilus spp.) followed by the Angoumois gelechiid (Sitotroga cerealella Olivier) and flour beetles (Tribolium spp.). High numbers of insects were recorded from both plastered and un-plastered gombisa and polypropylene bags. Additionally, the amount of every insect pest in each storage container recorded per $100 \mathrm{~g}$ grain increased because the duration of grain storage increased. There have been 0.33-1.29 and 0.44-1g droppings per 100-g sample of maize and sorghum grain, respectively. Grain damage showed significant differences over the storage periods across the study districts. A similar trend was observed for weight loss for each of the grains in all districts. These results indicated that farmers are incurring a substantial grain loss to insects and rodent pests. Hence, there is an urgent need to devise appropriate tactics for protecting the losses in farm-stored maize and sorghum in Ethiopia.

\section{Introduction}

Grains are the most important source of nutrition for one-third of the world's poorest population in Sub-Saharan Africa and South-East Asia. Among the grain crops, rice, wheat and maize represent about $85 \%$ of total global production (Sofi et al., 2009). In Ethiopia, Cereals constituted $87.3 \%$ of the grain production of the country, with $26.8 \%$ contribution from maize, $16.1 \%$ from sorghum and $15.7 \%$ from wheat (CSA, 2015). However, production of cereals and grains are constrained by various biotic and abiotic factors. Post-harvest losses are one among the most constraints affecting food and nutrition security of smallholding farmers within the country (Tefera, 2012; Tesfaye and Tirivayi, 2018). Poor storage systems make grains susceptible to attacks from insect and rodent pests, which cause a substantial amount of losses in quantity and quality of grains.

Losses resulting from poor post-harvest management of grains are among the key constraints for improving food and nutritional security in Africa that results in grain weight losses of 20-30\% (Tefera, 2012). Consistent with Kumar and Kalita (2017), approximately $50-60 \%$ loss of cereal grains occur during storage due to technical inefficiency. In Ethiopia, the typical grain losses owing to storage insect pests estimated to be $10-30 \%$ (Tadesse, 2005; MoARD, 2010). Among many storage insect pests, the rice weevils, Sitophilus spp. (Coleoptera:

Curculionidae), and the Angoumois gelechiid, Sitotroga cerealella (Olivier) (Lepidoptera: Gelechiidae), are major pests of cereal crops in Ethiopia (Tadesse, 1996; Demisse et al., 2008; Tefera, 2016). According to Sori and Ayana (2012), S. zeamais can cause heavy infestations on maize and sorghum grain stored under traditional storage facilities and resulted in weight loss up to $41-80 \%$.

Like those in other African countries farmer in Ethiopia, use traditional storage facilities such are gotera, gumbi, and polypropylene and jute bags. Gotera is an outside storage structure made up of mud or trash plastered basket work covered with thatched roofing and raised off the bottom with stones or wooden platform; Gumbi is an inside grain storage bin made from mud plaster mixed with teff straw (Hengsdijk and De Boer, 2017). Such storage structures often fail to guard the stored grains from insect pests and rodents. Traditional storage structures provide ideal 
conditions for the multiplication of storage insect pests and rodents. Although most smallholding farmers keep grain for a comparatively shorter period, substantial losses occur to stored grains.

Rodents are also considered as a serious postharvest pest, causing a big amount of losses and contamination of stored grains during storage which indirectly affects food security and income of the small-holder farmers (Brown et al., 2013; Ognakossan et al., 2016). To style effective postharvest pest management methods, knowledge of major pests and their relative abundances in reference to storage facilities is important. However, little information is there on storage insect pest infestations in reference to storage facilities. Therefore, the aim of this study was to assess storage insects of stored maize and sorghum and their associated losses of quantity in Southwestern Ethiopia.

\section{Materials And Methods}

\section{Study areas and sample collection methods}

Study areas included the select zones, Woredas and Kebele's depending on their potential towards maize and sorghum production and selection of farmers was made together with Woreda agricultural experts. It cover two major maize and sorghum producing zones of South-western Oromia, Ethiopia; namely, Jimma and West shawa. A total of $600 \mathrm{~g}$ grain sample of each storage structure was collected. The grain samples were taken from the top, middle and bottom of a storage structure and then bulked together to make a composite sample. Samples were collected at monthly intervals for up to five months from the same stores for storage insect pest studies, faecal dropping of rodent studies and grain damage and weight loss assessment. Sample collection was carried out after the grain was stored for one month and samples were enclosed in plastic bags and brought to the Postharvest Management Laboratory of Jimma University, College of Agriculture and Veterinary Medicine (JUCAVM) for laboratory analysis.

\section{Data collection}

\section{Identification of major insect pests}

About $100 \mathrm{~g}$ of sample was taken from each of the storage for the laboratory insect identification. The grain was sieved through $2 \mathrm{~mm}$ mesh sieve (to remove dead and alive insects from the sample taken and to leave the grain on sieve) as method used by Abraham, (1995). Both live and dead insects removed from each sample were counted, placed individually in a veil containing $70 \%$ ethanol and identified using the procedure described by Borror et al. (2005). The collected insects were identified through their morphological characteristics using a dissecting microscope (at a magnification of 25-60x) for species identification.

\section{Faecal dropping of rodent}

Sample of $100 \mathrm{~g}$ was taken from each of the storage for the identification of rodent faecal droppings. The sample was spread out on a plastic sheet to separate rodent faecal droppings. Faecal drooping removed from each sample were

Faecal dropping $=\frac{\text { Weight of faecal dropped }}{100 \mathrm{~g}}$ 
Assessment of damaged grain: Insect damage was recorded by the count and weighing method. Each $100 \mathrm{~g}$ grains were taken from initial to last storage periods and from each of the storage types and the number of insect damaged and un-damaged grains were determined using a hand lens by searching for the presence of hole on seeds. The percentage insect damaged grains was calculated according to the methods used by Wambugu et al. (2009) as follows,

\footnotetext{
Insect damaged grain $(\%)=\frac{\text { Number of insect damaged grain } x 100}{\text { Total number of grain }}$
}

Grain weight loss: For the assessment of grain weight loss, 100 grain samples were taken from initial to last storage periods and from each of the storage types and the number of insect damaged and un-damaged grains were identified and tallied using a hand lens to inspect for the presence of a hole or burrow. Grain in each portion were then counted and weighed using a digital balance. The percentage of weight loss was then calculated (Gwinner et al., 1996).

$$
\text { Weight loss }(\%)=\frac{(W u x N d)-(W d x N u) \times 100}{W u(W d+N u)}
$$

In the above formula, Wu is the weight of undamaged seeds, Nu is the number of undamaged seeds, Wd is the weight of damaged seeds and $\mathrm{Nd}$ is the number of damaged seeds.

\section{Data analysis}

A 2 × 3 factorial design was used for the analysis of damaged grain, weight loss of maize and sorghum grains stored in the farmers' traditional storage structures with two storage types (Gombisa/Gotera and polypropylene sack) and three storage duration levels $\left(1^{\text {st }}, 3^{\text {rd }}\right.$ and $5^{\text {th }}$ months). The data on the insect count, per cent grain damage and weight loss were analysed using one-way analysis of variance (ANOVA) with a generalized linear model. Then the data were arcsine transformed to normalize the variances. Significance level was set at 0.05 , and the means were separated by Tukey's Honestly Significant Difference test. All statistical analyses were conducted using MINITAB 16 statistical software.

\section{Results}

\section{Identification of storage insect pests}

Maize weevils (Sitophilus spp.), Angoumois grain moth (Sitotroga cerealella), and flour beetle (Tribolium spp.) were the insect species identified from both samples (Table 1). In Omo Nada district, there were significant differences in the number of maize weevil recorded during storage periods of stored maize $(P=0.05)$, but the storage type did not affect the number of insects. However, in Bako Tibe district, the number of maize weevils showed highly significant $(P=0.005)$ differences, with interaction effects of storage duration and storage types. Whereas, in stored sorghum grain there were significant differences in the number of maize weevil recorded during storage periods both in Omo Nada $(P=0.014)$ and Bako Tibe $(P=0.020)$ districts. In both districts, the number of Angoumois grain moth and flour beetle recorded in stored maize and sorghum were significantly affected by storage durations with the exception of flour beetle recorded in stored maize in Bako Tibe district.

Table 1: Number of insect pests sampled from maize and sorghum grains ( $100 \mathrm{~g}^{-1}$ grain) in the Omo Nada and Bako Tibe districts, Southwestern Ethiopia. 


\begin{tabular}{|c|c|c|c|c|c|c|c|}
\hline \multirow{2}{*}{$\begin{array}{l}\text { Grain } \\
\text { type }\end{array}$} & \multirow{2}{*}{$\begin{array}{l}\text { Storage } \\
\text { duration } \\
\text { (Months) }\end{array}$} & \multicolumn{3}{|l|}{ Gombisa } & \multicolumn{3}{|c|}{ Polypropylene bag } \\
\hline & & $\begin{array}{l}\text { Sitophilus } \\
\text { spp. }\end{array}$ & $\begin{array}{l}\text { Tribolium } \\
\text { spp. }\end{array}$ & $\begin{array}{l}\text { Sitotroga } \\
\text { cerealella }\end{array}$ & $\begin{array}{l}\text { Sitophilus } \\
\text { spp. }\end{array}$ & $\begin{array}{l}\text { Tribolium } \\
\text { spp. }\end{array}$ & $\begin{array}{l}\text { Sitotroga } \\
\text { Cerealella }\end{array}$ \\
\hline \multicolumn{8}{|c|}{ Omo Nada district } \\
\hline \multirow[t]{3}{*}{ Maize } & $1^{\text {st }}$ & $6.0 \pm 1.53^{a}$ & $2.0 \pm 1.53^{a}$ & $2.3 \pm 1.20^{\mathrm{ab}}$ & $4.7 \pm 1.85^{a}$ & $0.7 \pm 0.33^{b}$ & $1.3 \pm 0.33^{b}$ \\
\hline & $3^{\text {rd }}$ & $31.3 \pm 2.68^{b}$ & $3.3 \pm 0.88^{b}$ & $4.0 \pm 1.76^{\mathrm{ab}}$ & $8.0 \pm 1.73^{a}$ & $2.0 \pm 0.00^{\mathrm{ab}}$ & $6.3 \pm 2.18^{\mathrm{ab}}$ \\
\hline & $5^{\text {th }}$ & $36.3 \pm 2.64^{b}$ & $6.0 \pm 1.52^{\mathrm{a}}$ & $6.0 \pm 2.31^{a}$ & 7.3.0 $\pm 1.73^{a}$ & $4.0 \pm 1.00^{\mathrm{ab}}$ & $10.0 \pm 1.53^{a}$ \\
\hline \multirow[t]{3}{*}{ Sorghum } & $1^{\text {st }}$ & $8.7 \pm 2.18$ & $0.3 \pm 0.33$ & $0.7 \pm 0.67$ & $2.0 \pm 1.15$ & $0.0 \pm 0.00$ & $2.3 \pm 0.88$ \\
\hline & $3^{\text {rd }}$ & $9.3 \pm 1.20$ & $1.0 \pm 0.88$ & $3.7 \pm 1.86$ & $8.3 \pm 2.53$ & $1.3 \pm 0.67$ & $1.7 \pm 0.88$ \\
\hline & $5^{\text {th }}$ & $22.7 \pm 4.37$ & $5.3 \pm 2.85$ & $8.3 \pm 1.67$ & $20.3 \pm 3.22$ & $7.3 \pm 0.84$ & $7.0 \pm 4.73$ \\
\hline \multicolumn{8}{|c|}{ Bako Tibe district } \\
\hline \multirow[t]{3}{*}{ Maize } & $1^{\text {st }}$ & $2.7 \pm 2.18^{\mathrm{b}}$ & $0.3 \pm 0.33^{a}$ & $0.7 \pm 0.33^{a}$ & $2.7 \pm 1.45^{\mathrm{b}}$ & $0.7 \pm 0.67^{a}$ & $1.3 \pm 0.33^{b c}$ \\
\hline & $3^{\text {rd }}$ & $17.7 \pm 2.17^{b}$ & $1.0 \pm 0.58^{\mathrm{ab}}$ & $6.3 \pm 2.40^{\mathrm{abc}}$ & $12.0 \pm 1.53^{b}$ & $1.3 \pm 1.33^{\mathrm{a}}$ & $4.0 \pm 2.65^{\mathrm{abc}}$ \\
\hline & $5^{\text {th }}$ & $44.3 \pm 3.81^{\mathrm{a}}$ & $1.3 \pm 0.67^{\mathrm{ab}}$ & $11.3 \pm 2.60^{\mathrm{a}}$ & $15.0 \pm 3.00^{b}$ & $4.3 \pm 1.45^{\mathrm{b}}$ & $9.3 \pm 0.33^{\mathrm{ab}}$ \\
\hline \multirow[t]{3}{*}{ Sorghum } & $1^{\text {st }}$ & $5.3 \pm 0.67 b^{c}$ & $0.3 \pm 0.33$ & $0.3 \pm 0.11^{\mathrm{c}}$ & $1.7 \pm 0.88^{c}$ & $0.0 \pm 0.00$ & $1.7 \pm 0.67^{\mathrm{c}}$ \\
\hline & $3^{\text {rd }}$ & $19.3 \pm 3.22^{\mathrm{ab}}$ & $1.0 \pm 0.58$ & $3.0 \pm 1.53^{b c}$ & $9.7 \pm 0.88^{\mathrm{abc}}$ & $1.3 \pm 0.88$ & $2.0 \pm 1.15^{c}$ \\
\hline & $5^{\text {th }}$ & $25.0 \pm 4.00^{\mathrm{a}}$ & $2.7 \pm 1.33$ & $7.3 \pm 0.88^{\mathrm{ab}}$ & $21.3 \pm 2.41^{\mathrm{ab}}$ & $3.7 \pm 1.20$ & $7.7 \pm 0.88^{a}$ \\
\hline
\end{tabular}

Means within a column followed by different letters are significantly different at $\mathrm{P}<0.05$ (Tukey test). Note: Unplastered gombisa/gotera in Omo Nada and plastered gombisa/gotera in Bako Tibe district.

\section{Faecal droppings of rodent}

The result of faecal droppings in maize and sorghum grain stored in Gombisa during five consecutive months of storage period show in Figure 1. In Omo Nada faecal dropping collected from maize ranged from 0.33-1.29 g droppings $/ 100 \mathrm{~g}$ of sample, while in Bako Tibe it was ranged from 0.58-1.13g droppings $/ 100 \mathrm{~g}$ of maize. In Omo Nada it was ranged from 0.44-0.92g droppings $/ 100 \mathrm{~g}$ of sorghum, while in Bako Tibe it was ranged from 0.58-1 $\mathrm{g}$ droppings $/ 100 \mathrm{~g}$ of sorghum.

\section{Grain damage and weight loss}

The per cent damage of stored maize grain was significantly affected by storage type $\left(F_{1,12}=8.92 ; P<0.01\right)$ and storage duration $\left(\mathrm{F}_{2,12}=417.16 ; \mathrm{P}<0.001\right)$ with the highest per cent damage $(60.5 \pm 0.6)$ was observed in grain stored in Gombisa/Gotera at fifth month of storage (Table 2). The per cent damage of stored sorghum showed significant differences with storage duration $\left(F_{2,12}=335.73 ; P<0.001\right)$ (Table 2). In all grain types, damage increased with increase in storage duration (Table 2). 
Table 2. Insect damage (\% number) of maize and sorghum grains during storage in different storage structures from Southwestern Ethiopia.

\begin{tabular}{|lllll|}
\hline Grain type & Storage type & \multicolumn{3}{l|}{ Storage duration (months) } \\
\cline { 3 - 5 } & & $1^{\text {st }}$ & $3^{\text {rd }}$ & $5^{\text {th }}$ \\
\hline Maize & Gombisa/Gotera & $10.3 \pm 0.6^{\mathrm{d}}$ & $37.5 \pm 2.6^{\mathrm{c}}$ & $60.5 \pm 0.6^{\mathrm{a}}$ \\
\cline { 2 - 5 } & PP sack & $9.3 \pm 0.8^{\mathrm{d}}$ & $34.8 \pm 2.3^{\mathrm{c}}$ & $52.3 \pm 1.6^{\mathrm{b}}$ \\
\hline Sorghum & Gombisa/Gotera & $5.3 \pm 0.4^{\mathrm{c}}$ & $23.3 \pm 1.9^{\mathrm{b}}$ & $37.8 \pm 0.4^{\mathrm{a}}$ \\
\cline { 2 - 5 } & PP sack & $5.0 \pm 0.9^{\mathrm{c}}$ & $21.3 \pm 2.0^{\mathrm{b}}$ & $36.0 \pm 0.9^{\mathrm{a}}$ \\
\hline
\end{tabular}

Means within a column followed by different letter(s) are significantly different at $\mathrm{P}<0.05$ (Tukey test). Values are mean \pm SE.

The per cent weight loss $(\mathrm{WL})$ of stored maize grain was significantly affected by storage duration $\left(\mathrm{F}_{2,12}=310.82\right.$; $P<0.001)$. Similarly, the $W L$ of stored sorghum varied significantly among storage durations $\left(F_{2,12}=198.54 ; P<\right.$ 0.001). In all grain type, WL increased with increase in storage duration (Table 3).

Table 3. Mean percentage of weight loss of maize and sorghum grains during storage in different storage structures from Southwestern Ethiopia.

\begin{tabular}{|lllll|}
\hline Grain type & Storage type & \multicolumn{3}{l|}{ Storage duration (Months) } \\
\cline { 3 - 5 } & & $1^{\text {st }}$ & $3^{\text {rd }}$ & $5^{\text {th }}$ \\
\hline Maize & Gombisa/Gotera & $2.4 \pm 0.4^{\mathrm{c}}$ & $8.3 \pm 0.7^{\mathrm{b}}$ & $14.3 \pm 0.2^{\mathrm{a}}$ \\
\cline { 2 - 5 } & PP sack & $2.1 \pm 0.6^{\mathrm{c}}$ & $7.9 \pm 0.1^{\mathrm{b}}$ & $12.4 \pm 0.2^{\mathrm{a}}$ \\
\hline Sorghum & Gombisa/Gotera & $1.9 \pm 0.1^{\mathrm{c}}$ & $4.9 \pm 0.5^{\mathrm{b}}$ & $10.3 \pm 0.6^{\mathrm{a}}$ \\
\cline { 2 - 5 } & PP sack & $1.8 \pm 0.1^{\mathrm{c}}$ & $4.6 \pm 0.5^{\mathrm{b}}$ & $10.2 \pm 0.4^{\mathrm{a}}$ \\
\hline
\end{tabular}

Means within a column followed by different letter(s) are significantly different at $\mathrm{P}<0.05$ (Tukey test). Values are mean \pm SE.

\section{Discussion}

In the present study, Sitophilus spp., S.cerealella, and Tribolium spp. were recorded in maize and sorghum grains stored in gombisa and polypropylene bags storage containers. These species were reported as the main storage insect pests of cereal grains in several parts of Ethiopia (e.g., Mendesil et al. 2007; Demissie et al., 2008; Tadesse et al., 2008; Tefera, 2016) and other African countries (e.g., Tefera, 2012; Midega et al., 2016; Abass et al., 2018), in both studied districts and storage types, Sitophilus spp. were the foremost abundant species, which is corroborated by the findings of varied studies, like Mlambo et al. (2017). Angoumois moth is a cosmopolitan insect and therefore 
it is the dominant species attacking different cereal crops in Africa (Mlambo et al., 2017). Consistent with Golob (2002), S. cerealella is especially related to unshelled maize and sorghum soon after harvest. As demonstrated during this study, the amount of each storage insect pest recorded increased because the duration of grain storage increased, leading to considerable losses.

Tefera et al. (2011) observed a rise in grain damage and weight loss due to was increased density of storage insects and the duration of the storage period. In earlier studies, Dubale et al. (2012) observed a rise in density of maize weevil and Angoumois gelechiid on maize stored in Gombisa and sacks over the storage periods. Dubale et al. (2012) observed an increased density of maize weevil and Angoumois grain moth on maize stored in Gombisa and sacks over the storage periods.

The presence of faecal droppings in sample grain may be a sign of rodent infestation and it affects the standard attribute of stored grains (Brown et al., 2013). Faecal droppings per $100 \mathrm{~g}$ grain increased because the duration of grain storage increased this might flow from to a very fact that Gombisa a standard storage structures cannot protect rodent attack. Similar results were reported by Befikadu (2014), that on-farm storage structures like Gombisa make grain vulnerable to rodent infestation within the Southwestern part of the country due to the recent and humid climate, and these structures aren't highly protective generally. Rodents are one among the main postharvest pests causing a substantial amount of losses. During this study, most farmers considered rodents a significant problem that causes estimated grain losses of $26-50 \%$. A study conducted in Kenya showed that farmers perceived rodents causing up to $43 \%$ and $30 \%$ loss in maize stored on cobs and shelled grains, respectively (Ognakossan et al., 2016).

The results presented above shown that postharvest insect pests cause severe losses in stored grains for smallholding growers in Southwestern Ethiopia. Over 50\% and 35\% of damaged maize and sorghum grain, respectively, were observed by the fifth month of storage in Gombisa and polypropylene sack, which are the most common traditional storage structures in the study areas. Consistent with FAO (2010), an estimated loss of $20-30 \%$ occurred in Africa due to poor postharvest management practices. For instance, in Ethiopia, the typical grain loss due to storage insect pests is estimated to be 10 - 30\% (Tadesse, 2005; MoARD, 2010).

In Ethiopia, Sori and Ayana (2012) reported approximately $64.5 \%$ of grain damage in traditional farm stores within three to six months. Several factors like storage duration, storage type and management practice may have contributed to high grain damage by storage insect pests (Bounechada et al., 2011; Tefera, 2012). Grain weight loss from $10-15 \%$ in maize and sorghum were recorded during the fifth month of storage. Hell et al. (2012) observed 10 to $12 \%$ loss of grains stored in traditional storage structures due to insect pests in Tanzania. González-Torralba et al. (2013) noted that grain weight loss was found to be hooked in to storage duration, where a rise in storage time results in a big loss of grain weights. Furthermore, Tefera (2012) also reported that storage losses depend on temperature and humidity, which favour the expansion of mould and bug infestation.

\section{Conclusion}

In conclusion, no matter storage type, and therefore the traditional storage systems adopted by the farmers within the study areas couldn't effectively protect against storage losses caused by insect and rodent pests. As a result, grain damage consistently increased from the primary to the fifth months of storage. Similarly, grain weight loss increased because the duration of storage increased. This finding indicates the necessity for development of existing traditional storage facilities and therefore the adoption of improved storage facilities, like hermetic metal silos and PICS bags, which are proven to guard stored grains from insect pest infestation. 


\section{Declarations}

\section{Acknowledgements}

We want to thank Jimma University's College of Agriculture and Veterinary Medicine for financially supporting this research. The farming experts and farmers who have been involved in this report are also grateful to us. We are also thankful to Mr. Md. Jamshed Ali (Lecturer) of Department of Agro-Processing Ethiopian technical university, Holeta Satellite Campus, Ethiopia, provides technical support for this study.

\section{Conflicts of Interest}

The authors declare that they know the work reported in this paper is not in conflict with financial interests or personal relationships \& also no conflicts of interest between the authors.

\section{Availability of Data}

The data used to support the results of this study is available upon request from the corresponding author.

\section{Author contribution statement}

Marid Tadesse carried out the experiment, collected, analyzed data, and led the write-up of the manuscript. Md. Jamshed Ali, helped with provides technical support for this study. Both authors read and approved the final manuscript.

\section{References}

Abass, A.B., Fischler, M., Schneider, K., Daudi, S., Gaspar, A., Rüst, J., Kabula, E., Ndunguru, G., Madulu, D., \& Msola, D. (2018). On-farm comparison of different postharvest storage technologies in a maize farming system of Tanzania Central Corridor. Journal of Stored Products Research 77, 55-65.

Abraham T. (1995). Insects and other arthropods recorded from stored maize in western Ethiopia. ACSL 4(3):339343.

Befikadu, D. (2014). Factors affecting quality of grain stored in Ethiopian traditional storage structures and opportunities for improvement. International Journal of Sciences: Basic and Applied Research 18, 235-257.

Borror, D., De long, D., Triplehorn, C., \& Norman, F.J. (2005). Introduction to the study of insects. Peter marshal publisher, USA. pp; 377-610.

Bounechada, M., Fenni M., \& Benia F. (2011). Survey of insects pest stored and biological control of Trogoderma Granarium everts in Setifian Region (North -East of Algeria). Bulletin UASVM Agriculture 68, 70-74.

Brown, P.R., McWilliam, A., \& Khamphoukeo, K. (2013). Post-harvest damage to stored grain by rodents in village environments in Laos. International Bio deterioration and Biodegradation 82, 104-109

CSA (Central Statistical Agency). (2015). Agricultural Sample Survey, 2011/12 (2004 E.C.), Report on Area and Production of Crops, Volume I, Addis Ababa. Central Statistical Agency of the Federal Democratic Republic of Ethiopia. 
Demissie G, Tefera T, \& Abraham T. (2008). Efficacy of Silicosec, filter cake and wood ash against the maize weevil, Sitophilus zamias Motsch. (Coleoptera: Curculionidae) on three maize genotypes. Journal of Stored Products Research 40, 227-231

Dubale, B., Waktole, S., Solomon, A., Bulitosa, G., \& Sethu, M.R. (2012). Influence of Agro-ecologies, traditional storage containers, and major insect pests on stored maize (Zea mays L.) in selected woredas of Jimma Zone. Asian Journal of Plant Sciences 11, 226-234.

FAO/World Bank. (2010). FAO/World Bank Workshop on Reducing Post-Harvest Losses in Grain Supply Chains in Africa: Lessons learned and practical guidelines. FAO Headquarters, Rome, Italy, 18-19 March 2010, Rome.

Golob, P. (2002). Pest Management. In: Golob, P., Farrell, G., Orchard, J.E. (Eds). Crop Post-Harvest: Science and Technology, Volume 1: Principles and Practice. Wiley-Blackwell.

González-Torralba, J., Arazuri, S., Jarén, C. \& Arregui, L.M. (2013). Influence of temperatures and relative humidity during storage on wheat bread making quality. Journal of Stored Products Research55, 134-144.

Gwinner, J., Harnisch, R. \& Mück, O. (1996). Manual of the prevention of post-harvest grain losses. Manual of the prevention of post-harvest grain losses.

Hell, K., Ognakossan, K., Tonou, A.K., Lamboni, Y., Adabe, K.E. \& Coulibaly, O. (2012). Maize stored pests control by PICS-bags: technological and economic evaluation. IITA.

Hengsdijk H \& WJ De Boer. (2017). Post-harvest management and post-harvest losses of cereals in Ethiopia. Food Sec., 9:945-958.

Kumar, D., \& Kalita, P. (2017). Reducing postharvest losses during storage of grain crops to strengthen food security in developing countries. Foods 2017, 6- 8.

Mendesil, E., Abdeta, C., Tesfaye, A., Shumeta, Z., \& Jifar, H. (2007). Farmers' perceptions and management practices of insect pests on stored sorghum in southwestern Ethiopia. Crop Protection 26, 1817-1825.

Midega, C.A.O., Murage, A.W., Pittchar, J.O., \& Khan, Z.R. (2016). Managing storage pests of maize: Farmers' knowledge, perceptions and practices in western Kenya. Crop Protection 90, 142-149.

Mlambo, S., Mvumi, B.M., Stathers, T., Mubayiwa, M., \& Nyabako, T. (2017). Field efficacy of hermetic and other maize grain storage options under smallholder farmer management. Crop Protection 98, 198-210.

MoARD. (2010). Ethiopia's agricultural sector policy and investment framework (PIF): Ten Year Road Map (2010-2.020). Ministry of Agriculture and Rural Development. Federal Democratic Republic of Ethiopia. Addis Ababa, Ethiopia. 182 pp.

Ognakossan E, Affognon H, Mutungi C, Sila D, Midingoyi S-K, \& Owino W. (2016). On-farm maize storage systems and rodent postharvest losses in six maize growing agro-ecological zones of Kenya. Food Security 16, 1-21.

Sofi, P.A., Wani, S.A., Rather, A.G. \& Wani, S.H. (2009). Quality protein maize (QPM): genetic manipulation for the nutritional fortification of maize. Journal of Plant Breeding and Crop Science. 1(6): 244-253. 
Sori, W. \& Ayana, A. (2012). Storage pests of maize and their status in Jimma Zone, Ethiopia. African Journal of Agricultural Research 4056-4060.

Tadesse, A. (1996). Insects and other arthropods recorded from stored maize in western Ethiopia. African Crop Science Journal 4, 339-343.

Tadesse, A. (2005). Crop losses due to pre- and post-harvest pests and its attribution to food security. Paper presented at the workshop on prevention and disposal of obsolete pesticide stocks in Ethiopia- Phase II. 23-24 June 2005, CRDA, Addis Ababa. Crop Protection Department, MoARD.

Tadesse, A., A. Ayalew, E. Getu, \& T. Tefera. (2008). Review of research on postharvest pests. In increasing crop production through improved plant protection, volume I, ed. A. Tadesse, 475-562. Plant Protection Society of Ethiopia and EIAR, Addis Ababa, Ethiopia.

Tefera T. (2012). Post-harvest losses in African maize in the face of increasing food shortage. Food Security 4, 267277.

Tefera, T. (2016). Reducing post-harvest losses and increasing food availability. In: Belay Habtegebriel (Ed.), Postharvest Pest Management Research, Education and Extension in Ethiopia: The Status and Prospects. Proceedings of the $22^{\text {nd }}$ Annual Conference, March 10-420 11, 2016, Addis Ababa, Ethiopia, pp.23-30.

Tefera, T., Mugo, S., \& Likhayo, P. (2011). Effect of insect population density and storage time on grain damage and weight loss in maize due to the maize weevil, Sitophilus zeamaisand the larger grain borer, Prostephanus truncates. African Journal of Agricultural Research 6, 2249-2254.

Tesfaye, W. \& Tirivayi, N. (2018). The impacts of postharvest storage innovations on food security and welfare in Ethiopia. Food Policy 75, 52-67.

Wambugu, P.W., Mathenge, P.W., Auma, E.O. \& Van Rheenen, H.A. (2009). Efficacy of traditional maize (Zea mays L.) seed storage methods in western Kenya. African Journal of Food, Agriculture, Nutrition and Development. 9(4): 1110-1128

\section{Figures}



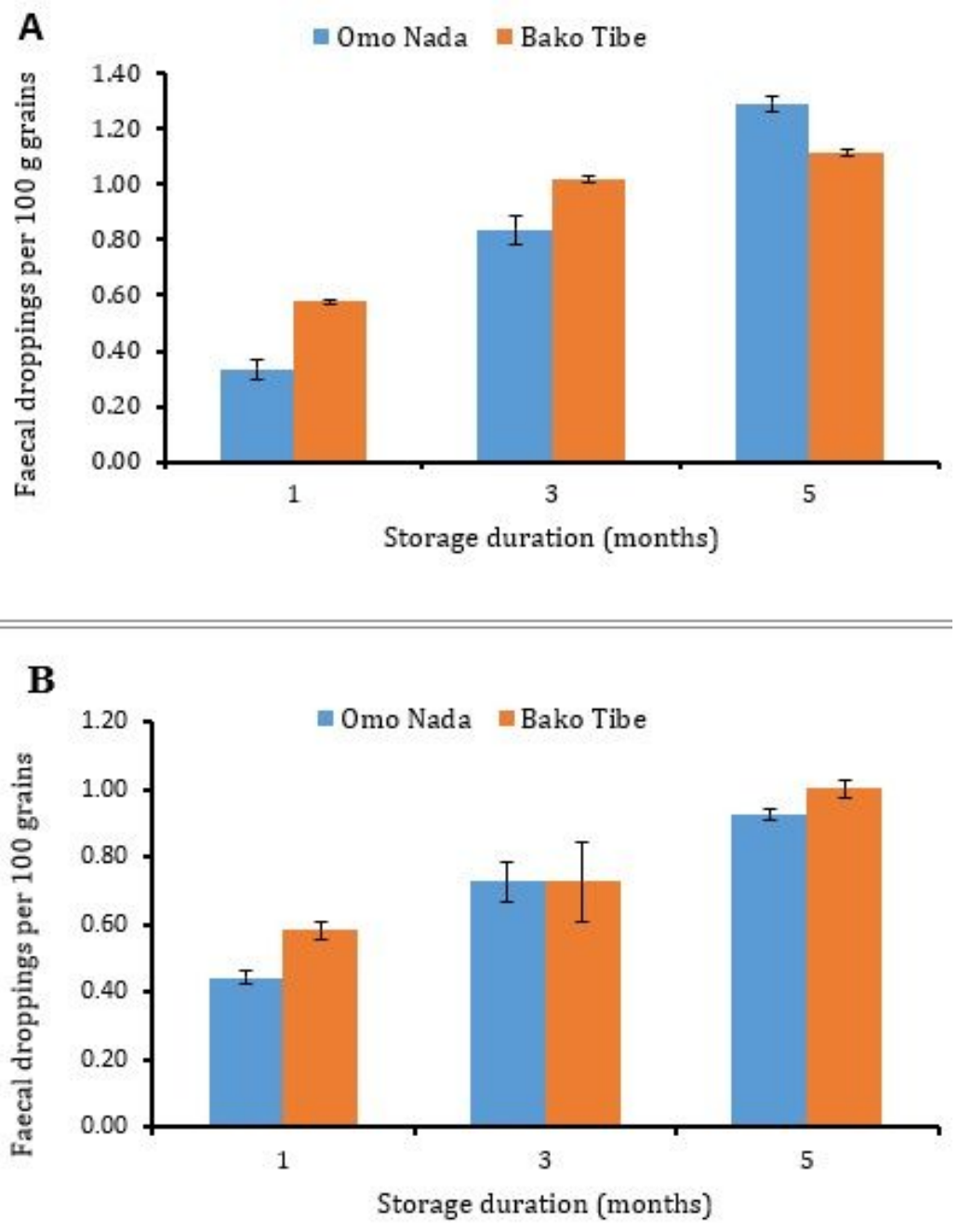

Figure 1

Rodent droppings per 100-g sample (mean \pm SE) from maize (A) and sorghum (B) grains sampled over five months in Omo Neda and Bako Tibe district, Southwestern Ethiopia. 